in single parent families, divorce and separation also lead to the need for assistance with parenting. Social problems such as drug and alcohol addiction, and mental instability are major reasons cited for parents not being able to raise their own children. Lastly, help with child care arises from two parents working and the need to cut down on child care costs.

These changes in child rearing practices are likely to affect the family system as we have known it. Parenting grandchildren has become such a visible issue in the United States that there is a proliferation of articles in magazines such as Modern Maturity. The American Association of Retired Persons has established a Grandparent Information Center, as a resource to assist grandparents in coping with this new role. Support groups and work-shops are also offered. Even health departments are issuing brochures specifically for grandparents on the care of young children citing good child health care practices and the need for immunizations and medical checkups. Perhaps the time-honoured developmental tasks of middle and older age will be challenged by these trends, and new societal norms or role expectations may emerge. More research is needed to investigate the great range of problematic and dynamic issues.

\title{
References
}

Aldous, J. 1995. New views of grandparents in intergenarational context. Journal of Family Issues, 16, 104-1 22.

Saluter, A. F. 1992. Marital Status and Living Arrangements: March 1991. Current Population Reports, Population Characteristics, Series P-20, No. 461 , United States Government Printing Office, Washington, D.C.

Nursing Program,

St Petersburg Junior College,

St Petersburg, Florida

\section{Payments for Care and Retirement Schemes}

Tony Maltby

Clare Ungerson, Gender, cash and informal care, Journal of Social Policy, 24 (I) (1 995), $3^{\mathrm{I}-52}$.

This article considers the important issue of 'payments for care' from a British perspective but with a European focus. The issue of 'payments for care' is of particular significance, the author argues, because with rising numbers of older people, most countries in Europe are following 
policies of 'care in the community' or 'decarceration' (as she rather brutally describes it) as the cheaper option. The advent of this policy has alerted researchers to consider whether payments are symbolic or reflect market rates. Perhaps the more important issue is the meaning ascribed to, and the policy implications of the use of, the phrase 'payments for care'. More especially, because the concept of care has a gendered meaning, she argues that 'feminists in particular must begin to formulate a view about them' (p. 39). The usual approach within the literature is to categorise care as informal or formal. The former is usually defined as being unpaid care within a domestic setting and it is normally understood to be born out of what Ungerson refers to as 'the operation of affect, biography and kinship' (p. 32). Formal care is waged and usually outside of the domestic setting. Thus a contrast is presented, a dichotomy of private or public caring. In addition, the perception is that the informal or private form is superior as is it based upon 'love' not money. However, Ungerson argues that informal care is increasingly becoming commodified. This runs counter to conventional wisdom, posing dilemmas particularly for feminists because of the new social and economic relations that arise from this shift. Her article considers the consequences to the caring relationship.

Her paper also attempts to advance the recent and important theoretical critique of the dichotomy between informal and formal care by Thomas (1993). From her research observations on the practical outcomes of various systems of 'payments for care', Ungerson argues that not only are conceptual boundaries breaking down (as Thomas suggests) but also empirical ones. Augmenting her other work on this issue (Balderson and Ungerson 1991, Ungerson 1990), as well as the work of Graham ( I 991 ), she discusses three types of payments for care that exist in Britain; 'symbolic payments to volunteers', and two forms of social security payments, one made to carers (the Invalid Care Allowance), and the other directly to disabled persons (the Attendance Allowance and the Severe Disablement Allowance). She broadens and complements this analysis by offering similar examples from other European countries. She concludes by arguing that the term 'quasiwages payments-for-care' be used for paid volunteering, because the payments are symbolic and not related to market rates, and that those payments which carers receive from benefit recipients are termed 'carer-allowance payments-for-care'. 
R. B. Hudson, The evolution of the welfare state: shifting rights and responsibilities for the old, International Social Security Review, 48 (I) (1995), 3-1 7.

P. Artus, The financing of retirement schemes, savings and growth, International Social Security Review, 47 (2) (1994), 3-16.

These two articles must be considered as thought pieces. Hudson's paper offers a critique of the neo-liberal approach to the welfare state and the threat this poses upon what he sees as its core tenets (i.e. universalism, adequacy and solidarity) through a consideration of policy for older people. Using examples from the United States and Europe, he suggests that since the I 970 two shifts or changes of focus have been responsible for undermining these core tenets. He recognises firstly a 'value shift' towards the centrality of paid work, and secondly a 'sector shift' away from public-centred programmes towards more 'market' orientated approaches. He then offers evidence from several countries of pensions systems that clearly demonstrate such shifts. The latter part of the paper argues for a strategy which enhances the 'core tenets' by steering a mid-course between on the one hand means-tested and residual programmes and on the other citizenship-based schemes.

The second paper considers in a technical yet interesting manner the dilemmas faced when choosing an appropriate form for the financing of retirement pensions schemes. In particular, the paper considers the financial implications of pay-as-you-go systems and of compulsory capital-accumulation schemes. There is a full mathematical analysis in the appendix for those who wish to pursue his more technical arguments. Following an informative discussion of the two methods of financing retirement schemes, the paper argues discursively the effects of introducing a scheme based upon capital-accumulation and it considers various refinements to the mainstream models. His conclusions are extremely important since they highlight the dilemmas currently faced by many governments not least in CEE countries.

\section{COMMENT}

These three papers raise in different ways interesting arguments and useful insights into the planning and future direction of social policy affecting older people. The two published in ISSR differ from Ungerson's paper by being concerned with what could be referred to as macro-economic and social planning. This may be a reflection of the very different audiences of the two journals. Some readers may be put off by the rather convoluted language used by Artus and Hudson but 
the content is fascinating and thought provoking. However, the arguments Hudson advances in his discussion of the 'shifts' are well rehearsed and not very illuminating. What is surprising (and pleasing) is his point that 'universalism, adequacy and progressivity can and should be maintained' (p. 3). Whether it will have any influence on governments is another matter. Ungerson's paper is an important contribution to feminist scholarship and extends the (mostly) academic discussion around 'payments for care'. Although her article is clearly directed at an academic audience, it is important also for raising issues which concern many professionals within Social Services Departments. However, although her discussion of 'payments for care' raises important issues, I do wonder whether inventing new terms (such as 'quasi-payments for care') adds to our understanding of the recent 'care in the community' policies.

\section{References}

Balderson, J. and Ungerson, C. r991. 'What d'ya want if you don' want money?' A feminist critique of paid volunteering. In Maclean, M. and Groves, D. (eds) Women's Issues in Social Policy, Routledge, London, pp. $13^{6-1} 5^{8 .}$

Graham, H. I991. The concept of caring in feminist research: the case of domestic service. Sociology, 25 (1), $6 \mathrm{I}-78$.

Thomas, C. 1993. Deconstructing concepts of care, Sociology, 27 (1), 649-669.

Ungerson, C. 1990. The language of care: crossing the boundaries. In Ungerson, $\mathrm{C}$. (ed.), Gender and Caring: Work and Welfare in Britain and Scandinavia, Harvester/ Wheatsheaf, Hemel Hempstead, Hertfordshire.

Department of Social Policy and Social Work, University of Birmingham 